\title{
Superior Palpebral Fold
}

National Cancer Institute

\section{Source}

National Cancer Institute. Superior Palpebral Fold. NCI Thesaurus. Code C33690.

A crease in the skin of the upper eyelid. 